\title{
ПРИНЦИПИ, МЕТОДИ ТА ПРИЙОМИ ПРОСТОРОВОЇ ОРГАНІЗАЦІЇ МІСТОБУДІВНОЇ СИСТЕМИ ЗАКЛАДІВ ОХОРОНИ ЗДОРОВ'Я
}

\author{
Булах I. В.
}

\section{ВСТУП}

Одним із пріоритетних завдань уряду України, виконання якого прописано в Конституції нашої держави, є формування ефективної архітектурно-містобудівної системи закладів охорони здоров'я, яка покликана на забезпечення якісною організацією та доступністю для всіх категорій населення. Для реалізації окресленого завдання, на жаль, виникає низка перешкод, пов'язаних із політичними, економічними, матеріально-ресурсними, соціальними, регіональними та іншими факторами. Для досягнення якісних змін в архітектурно-містобудівній організації системи охорони здоров'я сьогодні в Україні потрібно докорінно переосмислити та перебудувати усталену майже за століття мережу лікувальних закладів. Функціонуюча мережа закладів охорони здоров'я України була розроблена і реалізована у радянський період, цілком відповідаючи діючим на той час принципам і методам організації, типології, нормативним документам, різноманіттю лікарської спеціалізації, можливостям ресурсного та фінансового забезпечення. На жаль, найбільш гуманна до людини, безоплатна для громадян й одна 3 кращих в світі за рівнем охоплення населення, ця потужна архітектурно-містобудівна система лікувальних закладів за низкою обставин сьогодні не спроможна в повному і належному обсязі виконувати свої функції. Серед основних вад архітектурномістобудівної організації медичного обслуговування в Україні, розглянутих у попередніх дослідженнях ${ }^{1}$, необхідно підкреслити такі: інфантильність та недорозвиток первинного рівня медичної допомоги, надмірна кількість, дублювання закладів та спеціалізація госпітального рівня. Кожна $з$ окреслених проблем викликає багаторівневі похідні обтяження, які у сукупності 3 відсутністю регулярних покрокових реформ галузі та іï недофінансуванням, призвели до кризисної ситуації

${ }^{1}$ Булах І.В. Передумови реорганізації мережі дитячих лікувальних закладів України. Сучасні проблеми архітектури та містобудування. Київ, 2017. № 47. C. $444-450$. 
в охороні здоров'я нашої країни. Підтвердженням слугує те, що колись зразкова організація охорони здоров'я України, у 2017 р. отримала 135 місце 3148 можливих у рейтингу рівня розвитку медицини в країнах світу, знаходячись позаду Судану (131-е місце), Іраку (132-е місце), Афганістану (133-е місце), Мадагаскару (134-е місце) i поряд 3 Конго, Анголою, Угандою, Нігерією та іншими африканськими країнами ${ }^{2}$.

\section{1. Медичні передумови розвитку \\ містобудівної системи закладів охорони здоров'я}

Для вирішення ситуації, що сталася, у дослідженні містобудівна система закладів охорони здоров'я розглядається як складна ієрархічна структура, основними ієрархічними компонентами якої виступають містобудівні мережі закладів первинного, вторинного та третинного рівнів медичного обслуговування населення. Запропонована концепція базується на системному підході, за якого зазначені мережі $\epsilon$ складовими елементами цілісної системи охорони здоров'я України, володіючи при цьому певною автономністю, виконуючи власні функції, а також забезпечуючи поступовість і доступність населення до отримання сучасних i якісних медичних послуг. Концепція $є$ результатом аналізу теорії та практики архітектурно-містобудівної організації закладів охорони здоров'я в провідних країнах світу ${ }^{3,4,5}$, а також пострадянських країн, які досягли успіхів у архітектурно-містобудівної реорганізації лікувальних закладів.

Перспектива закономірного розвитку містобудівної системи закладів охорони здоров'я України повинна формуватись на основі нових засадничих медичних принципів, оголошених у межах напряму реформи галузі ${ }^{6}$, серед яких особливо вагомими

2 The Legatum Institute: рейтинг розвитку медицини в країнах світу в 2017 р.

${ }^{3}$ Булах I.В. Сучасний закордонний досвід проектування енергоефективних лікарень (досвід Сінгапура). Сучасні проблеми архітектури та містобудування. Київ, 2018. № 50. С. 332-440.

4 Булах I.В. Досвід організації системи охорони здоров'я у Сполучених Штатах Америки та Франції із визначенням у них місця мережі дитячих лікувальних закладів. Сучасні проблеми архітектури та містобудування. Київ, 2018. № 52. С. 165-173.

Булах I.В. Архітектурно-містобудівна організація закладів охорони здоров'я Німеччини та Великобританії. Сучасні проблеми архітектури та містобудування. Київ, 2019. № 53. С. 126-134.

6 Міністерство охорони здоров'я: Національна стратегія реформування системи охорони здоров'я в Україні на період 2015-2020 років. 
виявляються наступні: орієнтованість на людей, орієнтованість на результат та орієнтованість на втілення. Орієнтованість на людей означає, що система повинна відповідати сучасним потребам суспільства. Якість організації та умов надання медичних послуг, здатність адаптуватися під мінливі потреби та можливості виступають фундаментальною основою у процесі реформування системи охорони здоров'я. Структурна побудова системи охорони здоров'я складається 3 низки соціальних інституцій, злагоджена робота яких залежить від злагоджених відносин між компонентами системи, включаючи управлінські, постачальні і отримуючи медичне обслуговування, науково-дослідницькі і освітні підрозділи тощо. Цей медичний принцип свідчить про необхідність забезпечення доступного функціонального та архітектурно-містобудівного взаємозв'язку між містобудівними мережами медичного обслуговування та їх відповідними складовими закладами охорони здоров'я у різноманітті типів розпланувань міських та сільських поселень України. В аспекті медичного обслуговування дітей цей принцип найбільш розкривається у змісті концепції дитячого лікувального комплексу - забезпечення якісного та доступного лікування дітей, 3 можливістю вибору у різноманітті сучасних закладів охорони здоров'я, максимально наближених до місць проживання пацієнтів.

Принцип орієнтованості на результат націлений на зумовлення прийняття рішень на усіх рівнях організації та управління сфери охорони здоров'я на основі кінцевої результативності медичної допомоги, ефективності використаних ресурсів та коштів, комплексної оцінки результату діяльності пацієнтами. 3 метою підвищення результативності система охорони здоров'я повинна інтегрувати сучасний досвід менеджменту та управління, робота яких пов'язана з регулярною оцінкою виконання етапів та кінцевих результатів, внесення на цій основі пропозицій щодо удосконалення та покращення подальшої роботи, виявлення перспективних шляхів розвитку та усунення неефективних елементів. Вказаний принцип свідчить про важливість задоволення потреб суспільства не кількісним, а якісним рівнем забезпечення медичного обслуговування, про необхідність скорочення малоефективної, застарілої та дубльованої множини лікувальних закладів. Принцип вказує на пріоритет розвитку містобудівної мережі ПМД для попереджування гострих станів захворюваності населення, зниження навантаження на госпітальні рівні.

Медичний принцип орієнтованості на втілення спрямований на активізацію послідовної підготовчої роботи до отримання намічених 
результатів, організації моніторингу, розробки механізмів корегування, часових меж реалізації. Проекція змісту принципу на тему дослідження підкреслює значимість динамічного та змінного складника розвитку містобудівної системи закладів охорони здоров'я, потребу у іiі синергетичних процесах, самоорганізації, саморегуляції та адаптації під мінливі демографічно-соціальні, політично-економічні, епідеміологічні, містобудівні та інші умови, можливості та виклики. Для реалізації зазначеного принципу в організацію архітектурномістобудівної системи закладів охорони здоров'я потрібно долучати позитивні риси ринкових відносин, конкуренції, моніторингу ефективності, досвід впровадження і роботу яких можна спостерігати на практиці приватних медичних закладів.

Окрім розглянутих медичних принципів та положень, слід відмітити загальні принципи, притаманні сучасному розвитку архітектурно-містобудівної проектної діяльності, серед яких: гнучкість, варіативність, багатофункціональність, естетизація проектних рішень. Принцип гнучкості полягає у трансформативних якостях, у забезпеченні можливості та умов для проведення корегування і удосконалення лікувальних процесів, зміни методів і форм медично-технічного обслуговування, залежно від потреб і можливостей населення України. В більшості країн 3 високим рівнем розвитку системи охорони здоров'я розповсюдженими виявились інноваційні методи медичного обслуговування, такі як: телемедицина, інтерактивні, відео та електронні засоби спілкування, консультацій, обговорень, перевірки діагнозів та методів лікування, навчання та інші ${ }^{78}$. Зазначені новітні методи організації медичного обслуговування, безумовно, слід відносити до допоміжних заходів, які, однак, потребують врахування під час архітектурномістобудівної організації системи, особливо у сільській місцевості, де не завжди $€$ можливість створення повноцінної медичноматеріальної бази. Принщии варіативності та багатофункціональності під час формування містобудівної системи лікувальних закладів та комплексів, складових мереж всіх рівнів медичного обслуговування визначає динамічні властивості

${ }^{7}$ Bulakh I., Kozakova O., Didichenko M. The innovative trends in architecture and urban planning of health care institutions. International Journal of Innovative Technology and Exploring Engineering. Bhopal, 2019. Vol. 9. Issue 1. Pp. 317-323. DOI: 10.35940/ijitee.A4111.119119

${ }^{8}$ Bulakh I., Kozakova L., Didichenko M., Chala O. Health Care Architectural and Urban Planning Systems In The United States of America and France. International Journal of Innovative Technology and Exploring Engineering. Bhopal, 2019. Vol. 9(2). Pp. 1622-1627. DOI:10.35940/ijitee.B7377.129219 
цілісності, іï окремих складових елементів, 3 можливістю в разі потреби перепрофілізації лікувального закладу або його відділень, зміни структури та місткості. Принщии естетизащії ma індивідуалізаиії передбачає активізацію потенцій лікувальних властивостей зовнішнього та внутрішнього середовища медичних будівель, благоустрою та дизайну ландшафту їх територій, з урахуванням індивідуальних потреб та особливостей людей і особливо дітей. Тривалий уніфікований та типово-індустріальний підхід до проектування та будівництва закладів охорони здоров'я, притаманний пострадянським країнам, на жаль, був спрямований на створення i функціонування лікувального закладу на зразок «машини» для лікування знеособленого населення, без «зайвих» ознак краси, людяності, відчуття співмасштабності та співчуття 9 .

\section{2. Процеси та принципи закономірного розвитку містобудівної системи закладів охорони здоров'я}

Для реалізації нових медичних положень, загальних сучасних принципів розвитку містобудівної проектної діяльності, беручи до уваги глобальні процеси урбанізації міського середовища одночасно 3 обмеженням у вільних земельних ресурсах, ритму і темпу суспільного життя, а також відсутність необхідного забезпечення у фінансуванні сфери охорони здоров'я України, варто шукати нових принципів містобудівного розвитку системи, іiї складових мереж. Відштовхуючись від фундаментальної тріади Вітрувія про сутність архітектури, у дослідженні пропонуються матриця структуроформуючих містобудівних процесів побудови принципів динамічного розвитку системи дитячих лікувальних комплексів. Запропонована матриця дозволяє систематизувати та описати процеси, які характерні для динамічного розвитку складових компонентів містобудівної системи закладів охорони здоров'я містобудівних мереж первинної (ПМД), вторинної (ВМД) та третинної (ТМД) медичної допомоги, а також загальносистемні закономірні явища.

Перша сходинка та ієрархічний рівень системи - містобудівна мережа закладів ПМД відповідає за «міцність» і «форму» побудови системи, виступаючи при цьому матеріальною основою закономірного розвитку системи дитячих лікувальних комплексів.

${ }^{9}$ Bulakh I.V. Artistic and Aesthetic Formation and Evolution of Architectural and Urban Planning Space. Science and Innovation. Kyiv, 2019. Volume 15. No 5(5). pp. 57-66. DOI: 10.15407/scine15.05.057 
Наступний рівень - містобудівна мережа закладів ВМД відповідає за «користь» і структурну побудову системи, виступаючи при цьому функціональною основою закономірного розвитку системи дитячих лікувальних комплексів. Третій ієрархічний рівень - містобудівна мережа закладів ТМД, потребує розширення тріади Вітрувія 3 введенням «унікальності» організаційної побудови системи, виступаючи при цьому спорадичною основою закономірного розвитку містобудівної системи.

Загальносистемні процеси, які водночас притаманні як окремим елементам системи, так і іï цілісності, відповідають за доцільність системи, виступаючи гармонійною основою побудови і динамічного розвитку містобудівної системи. Динамічна основа загальносистемних процесів системи відповідає за «міцність», синергетична основа - за «користь», індивідуальна основа - за «красу» побудови і закономірного розвитку містобудівної системи закладів охорони здоров'я. Сукупність запропонованих 3 мережевих та 3 загальносистемних процесів виступила підгрунтям для формування матриці 324 відповідних закономірних структуроформуючих містобудівних принципів (6 базових та 18 похідних) динамічного розвитку містобудівної системи закладів охорони здоров'я. Базові принципи відповідають за побудову містобудівних рівнів системи та ії цілісності, похідні принципи уточнюють дію базових у різноманітті видів поселень, а також на загальнодержавному рівні.

Перший базовий прини̧ип розосередження спрямований на дифракцію та розгалуженість містобудівної мережі закладів ПМД шляхом іiі подрібнення до стану, що відповідає доступності та потребам суспільства. Принцип розосередження передбачає динамічну структуру, яка має хвилеподібний змінний характер, що дозволяє збільшувати та зменшувати кількість закладів ПМД у структурі населених пунктів залежно від демографічно-соціальних та урбаністичних явищ, попиту та потреб на медичне обслуговування. На державному рівні принцип трансформується у похідний принцип розгалуженість, метою якого виступає формування різноманіття лікувальних закладів первинної ланки 3 покриттям доступного медичного обслуговування до 90\% населення країни. У міському середовищі найкрупніших, крупних та великих міст пропонується видозміна принципу у явище локальності, що пов'язано 3 гетерогенною структурою міської тканини, неоднорідністю кількості і щільності населення у різних міських 
районах, а також хвилеподібною часткою дитячої категорії в них. Для групи середніх та малих міст, а також сільської місцевості, в яких спостерігаються найменші показники щільності забудови та проживаючого населення, при цьому збільшуються рекомендовані нормативні значення, принцип набирає вираження детермінованості, тобто найменшої просторово-часової змінюваності та відносної стабільності.

Другий основний принцип комплексності відповідає за конгруентність, універсальність та багатопрофільність лікувальних закладів вторинної містобудівної ланки медичної допомоги, їх взаємну узгодженість між собою у складі цілісності системи. Відповідаючи за функціонування містобудівної системи лікувальних закладів на державному рівні, принцип характеризується як синтезування основних типів вторинного госпітального рівня на шляху забезпечення повноцінною лікарняною допомогою усіх вікових категорій населення. Для міського середовища найкрупніших, крупних та великих міст актуальним значенням принципу виявляється повторення або реплікація, тобто знаходження необхідної кількості та місткості лікарень ВМД шляхом їх повторення (але не дублювання) у межах міських територій в узгодженості із рекомендованими нормативними показниками. Група середніх та малих міст, території сільської місцевості потребує трансформації значення принципу у розсіяння або дисперсію, тобто за необхідності допустима організація дрібних лікарень інтенсивного лікування 3 метою дотримання нормативних радіусів доступності або їх зменшення, у разі незадовільного стану транспортної інфраструктури, 3 одночасним відхиленням (у бік збільшення) від рекомендованих часових показників інших типів лікарень ВМД.

Третій засадничий принцип іррегулярності, який відповідає за містобудівну організацію мережі закладів третинної медичної допомоги, сприяє формуванню нерегулярного розміщення спеціалізованих та унікальних лікарень та їх комплексів. На рівні державної організації містобудівної системи закладів охорони здоров'я дія принципу спрямовується на поляризацію, покликану на забезпечення територіально-планувальних функціональних зв'язків між спеціалізованими лікарняними структурами в межах території країни. У разі розміщення закладів ТМД у середовищі найкрупніших, крупних та великих міст принцип отримує ознаки концентраціï, тобто пошуку стану рівноваги у потенції та потребі спеціалізації медичної допомоги та відповідної доцільності. 
Сукупність середніх, малих міст, сільська місцевість вимагає видозміни принципу у розрідженість, що пов'язано із унеможливленням забезпечення покриття якісним спеціалізованим медичним обслуговуванням територій 3 розрідженою щільністю проживаючого населення, водночас з потребою іiї концентрації на регіональних (госпітальних) рівнях.

Впровадження четвертого базового принципу фрактальності створює умови для активізації здатності містобудівної системи закладів охорони здоров'я до динамічного та закономірного синергетичного розвитку у просторі і часі на основі самоорганізації, саморегуляції шляхом утворення самоподібних структур. На рівні загальнодержавного формування містобудівної мережі закладів охорони здоров'я принцип трактується як тяжіння або атракторізація, передбачає множину станів (етапів) або точок фазового простору динамічної містобудівної системи лікувальних закладів, до якої вона прямує у часо-просторовому вимірі. Рівень міського середовища найкрупніших, крупних та великих міст потребує інтерпретації принципу як метаболізм, тобто динамічного стану оновлення кількості, місткості та локалізації складових елементів містобудівної системи лікувальних закладів шляхом попереднього їх розміщення на основі граничних нормативних показників та поступового корегування в узгодженості 3 прогнозними та об'єктивними потребами та попитом суспільства. Групу середніх та малих міст, території сільської місцевості доцільно розглядати з позиції повторювання або ітерації в аспекті збільшення типів і кількості лікувальних закладів, їх територіальної концентрації до поступового наближення до нормативних рекомендацій.

Наступний засадничий принцип - кластерність, відповідальний за територіальне утворення всередині містобудівної системи закладів охорони здоров'я відносно автономних одиниць (комплексів), які забезпечують повний цикл медичного обслуговування за певним напрямом. Пропонується така класифікація медичних кластерів: за містобудівним рівнем (первинного, вторинного, третинного медичного обслуговування); за територіальними межами (функціонування низки об'єднаних лікувальних закладів на визначеній території регіону, міста); за профілем компонентів (лікувальні, освітні, науково-дослідні заклади, складові медичної промисловості інші супутні та допоміжні структури); за напрямом спеціалізації (дитячі, кардіологічні, 
онкологічні, психоневрологічні, нефрологічні, трансплантаційні та інші спеціалізовані лікарні), за віковою категорією пацієнтів (дитяче, доросле, населення похилого віку). Особливість та специфіка медичних кластерів полягає в тому, що на шляху до емерджентних результатів в них можуть бути задіяні компоненти 3 різних містобудівних рівнів та мереж містобудівної системи закладів охорони здоров'я, а також з інших суміжних та допоміжних сфер (освітньої, науково-дослідної, промислової та інших).

На державному рівні організації містобудівної системи лікувальних закладів принцип видозмінюється у напрямі інтегральності різноманіття складових кластерів 3 метою координації їх розвитку. У міському середовищі найкрупніших, крупних та великих міст, у яких одночасно існують різні типи кластерних об'єднань, доцільна інтерпретація принципу як консолідованість, тобто формування різнобічних внутрішніх та зовнішніх взаємозв'язків між окремими кластерами з метою емерджентного результату за рахунок об'єднання, інтеграції та згуртованості. Група середніх та малих міст, території сільської місцевості вимагають трансформації принципу у комутаційність (лат. commutatio - зміна, commutare - змінювати), яка пов'язана 3 пошуком та встановленням зв'язків між окремими лікувальними закладами, їх комплексами у певній територіальній одиниці та поза іiі межами.

Останній стрижневий принцип - своєрідність, який покликаний створити підгрунтя для індивідуалізації архітектурно-містобудівних проектних рішень під час формування містобудівної системи закладів охорони здоров'я. На загальнодержавному планувальному рівні принцип отримує ознак регіональності, яка передбачає інтеграцію низки територіальних особливостей, потрібностей та потенцій у динамічному розвитку містобудівної системи закладів охорони здоров'я. Розуміння принципу як ідентичності доцільно у разі планування лікувальних закладів у містобудівному середовищі найкрупніших, крупних та великих міських поселень. У цьому разі ідентичність націлена на ув'язку сукупності впливових зовнішніх та внутрішніх факторів, різноманіття середовищ міських контекстів, оточуючої забудови та перспектив розвитку кожного окремого і сформованого міста. У містобудівному середовищі середніх та малих міських поселень, а також для територій сільських населених пунктів доцільна інтерпретація принципу у значенні ініціалізації, пов'язаної з потребою у новій розбудові 
містобудівної системи лікувальних закладів, іiі активації, у індивідуальному визначенні та поступовому корегуванні параметрів функціонування та динамічного розвитку.

\section{3. Методи і прийоми формування і розвитку містобудівної системи закладів охорони здоров'я}

Обгрунтування принципів територіальної організації містобудівної системи закладів охорони здоров'я стало підгрунтям для визначення методів реалізації мережі дитячих лікувальних комплексів. 3 огляду на октаедртність основоположних принципів містобудівного формування системи лікувальних закладів та тесерактовість кумулятивної матриці засадничих та похідних принципів у дослідженні пропонується 6 груп методів і 18 прийомів ix реалізації. Перша група, яка підпорядкована принципу розосередження та спрямована на розгалуження містобудівної мережі первинної ланки, складається із методу дифузії та низки прийомів (розподілу, насичення, достатності). Друга група, заснована на принципі комплексності і відповідна за універсальність та багатопрофільність лікувальних закладів вторинної ланки медичної допомоги, складається із методу поліфонічності та прийомів ансамблевості, ритмічності, асиметричності. Третя група, пов'язана із принципом іррегулярності містобудівної організації госпітальної мережі ТМД, спрямована на нерегулярне розміщення спеціалізованих лікарень, реалізується методом вибірковасті та прийомами присднання, відокремлення, групування. Четверта група, яка складається 3 методу генеративності i прийомів поєднаності, відмінності та подібності, підкорюється дії принципу фрактальності, що відповідає за самоорганізацію та саморегуляцію містобудівної системи закладів охорони здоров'я. П'ята група методу скупчення та прийомів взаємозв'язковості, інтеграції та розсіювання, пов'язана із принципом кластерності, які у сукупності ставлять на меті територіальне угрупування та взаємозв'язок різнорідних лікувальних комплексів, в тому числі дитячої спрямованості. Остання група, представлена методом контекстуальності та прийомами протиставлення, палімпсесту та новаційності, зв'язана із активацією принципу своєрідності, відповідає за самобутність та індивідуалізацію архітектурно-містобудівного проектування цілісності містобудівної системи закладів охорони здоров'я. 
Метод дифузії - процес насичення міської тканини типологічним різноманіттям закладів первинної медичної допомоги, 3 метою вирівнювання їх концентрації до нормативних показників із урахуванням щільності проживаючого населення у сукупності планувальних одиниць території міського середовища. На загальнодержавному рівні формування і розвитку містобудівної системи лікувальних комплексів метод дифузії вмикає дію прийому насичення, який корегує міру зростання або спадання кількості i потужності закладів первинної медичної ланки у суцільному територіальному вимірі країни. Прийом розподілу або екстрагування, який передбачає розподіл міської території на ділянки із різним характером забудови (історична, типова, висотна, малоповерхова, ущільнена та інші) та відмінною кількістю населення, доцільно використовувати у міському середовищі найкрупніших, крупних та великих міст. На цій основі обираються оптимальні типи закладів ПМД, формуються відповідні комбінації 3 ïx нерівномірним розміщенням у різноманітті структури міста. Для групи середніх та малих міст, а також сільської місцевості метод дифузії доцільно здійснювати шляхом використання прийому достатності, покликаного на організацію дрібних осередків надання ПМД у населених пунктах з низькою щільністю забудови та проживаючого населення.

Для пояснення шляхів реалізації першої групи методу і прийомів доцільно проаналізувати існуючий стан та надати пропозиції щодо формування складових компонентів дитячого лікувального комплексу на рівні мережі закладів ПМД у межах м. Києва. Незважаючи на кращій в країні рівень розгалуженості мережі комунальних та приватних закладів ПМД, особливо сконцентрованих у центральних та історичних міських зонах, аналіз показників щільності проживаючого населення по різних міських ділянках свідчить про нестачу медичних закладів на периферії та у районах з активним висотним житловим будівництвом. Комбінація принципів розосередження та локальності дозволяє розмістити нові місця для надання медичних послуг ПМД в залежності від наявних та прогнозних потреб на міських ділянках з прискореним темпом житлового будівництва. Використання методу дифузії дозволяє наситити міську тканину типологічним різнобарв'ям закладів ПМД до стану, відповідного до нормативних показників, щільності населення. Прийом розподілу корегує заповнення проблемних 
ділянок міської території 3 позиції характерних особливостей забудови, іiі висотності, ущільненості та ін.

Метод поліфонічності, призначений для активізації принципу комплексності та територіальної трансформації багатопрофільних лікарень за 6 ступенями інтенсивності лікування, 3 одночасною інтеграцією дитячих відділень у структуру їх функціональної побудови 3 метою усунення спеціалізації госпітальних закладів за віковими ознаками. Реалізації методу на загальнодержавному рівні формування стає можливою під впливом прийому ансамблевості, відповідного за різноманітність функціональної структури госпітальної мережі вторинної ланки медичного обслуговування населення країни. Прийом ритмічності, тобто розміреності і узгодженості територіального розміщення типологічних різновидів лікарень ВМД доцільно використовувати у міському середовищі найкрупніших, крупних та великих міст. Для групи середніх та малих міст, а також сільської місцевості метод поліфонічності доцільно здійснювати шляхом використання прийому асиметричності, покликаного на формування нерівномірної структури містобудівної мережі лікарень ВМД, що пов'язано з демографічною розрідженістю проживаючого населення та незначною щільністю забудови.

Ілюстрацією механізмів дії другої групи методу і прийомів, пов'язаних iз принципом комплексності, слугує діагностика існуючого положення та пропозиції щодо формування і розвитку складових компонентів дитячого лікувального комплексу на рівні містобудівної мережі закладів ВМД на прикладі м. Києва. Згідно $з$ проведеним у дослідженні аналізом існуючого стану госпітальної мережі неспеціалізованих лікарень та особливостей їх містобудівного розміщення в м. Києві функціонує 16 багатопрофільних лікарень, призначених для обслуговування дорослої категорії населення (Київська міська клінічна лікарня № 1-№ 10, № 12, № 14, № 15, № 17, № 18 та Олександрівська клінічна лікарня), 3 яких 12 закладів знаходяться у правобережній частині міста, а 4 лікарні забезпечують госпітальну медичну допомогу дорослим мешканцям міста на лівобережжі столиці держави. Характерним недоліком фактичного територіального розміщення лікарень містобудівної мережі вторинної медичної ланки виступає їх згуртованість та дублювання, яке особливо виражене в історичній частині міста. Окрім цього, частина з цих лікарень побудована у 
першій половині XX сторіччя, має фізичне зношення, нераціонально використовує земельну ділянку.

Пропонується наступний перерозподіл: 4 багатопрофільні лікарні інтенсивного лікування (Київська міська клінічна лікарня швидкої медичної допомоги, Київська міська клінічна лікарня № 8, Київська міська клінічна лікарня інтенсивного лікування № 3, Київська міська клінічна лікарня № 6); 2 лікарні відновного лікування (Київська міська клінічна лікарня № 2, Київська міська клінічна лікарня № 14); 4 лікарні планового лікування (Київська міська клінічна лікарня № 1, Київська міська клінічна лікарня № 4, Київська міська клінічна лікарня № 9, Київська міська клінічна лікарня № 12); 2 хоспіса (Київська міська клінічна лікарня № 7, Олександрівська клінічна лікарня); 2 лікарні медико-соціальної допомоги (Київська міська клінічна лікарня № 17, Київська міська клінічна лікарня №18); 6 перинатальних центрів (пологовий будинок № 4, № 7, ПАГ, Isida, Adonis, Лелека), 2 пологових будинки (пологовий будинок при Київській міській клінічній лікарні №1, пологовий будинок № 5).

У Києві функціонує 11 комунальних пологових будинків та 3 приватні, більшість 3 яких згідно 3 територіальним аналізом концентруються поруч один з одним, тим самим дублюючи функції. Пропозиціями щодо містобудівного розташування зазначених лікувальних закладів виступають такі: надати статус перинатальних центрів 6 пологовим будинкам (3 приватним та 3 комунальним) та залишити 2 пологових будинки, які рівномірно охоплюють територію міста. Інші наявні пологові лікарні пропонується перепрофілювати під інші функції або використовувати як перинатальні центри приватної чи змішаної форми підпорядкування та фінансування. У перспективі необхідно влаштування перинатальних центрів у периферійній частині Голосіївського та Деснянського районів.

Метод вибірковості призначений для виявлення та грунтовного аналізу провідних напрямів лікувальної діяльності лікарняних структур 3 метою виявлення або спростовування доцільності їх спеціалізації й приєднання до містобудівної мережі третинного медичного забезпечення. Прийом групування дозволяє на рівні території держави забезпечити формування містобудівної спеціалізованої госпітальної системи, яка створює необхідні умови та потенції для прогресивного та інноваційного розвитку локальних осередків з лікувальними, освітніми, науково-дослідними та 
експериментально-виробничими функціями. Прийом відокремлення пов'язаний 3 виокремленням та формуванням спеціалізованих та унікальних лікарень у міському середовищі найкрупніших, крупних та великих міст. Для групи середніх, малих міст, сільської місцевості, метод вибірковості реалізується завдяки використанню прийому приєднання, покликаного на пошук і встановлення територіальних зв'язків з найближчими спеціалізованими закладами містобудівної мережі лікарень ТМД.

Для пояснення шляхів реалізації третьої групи методу і прийомів, пов'язаних із принципом іррегулярності, у дослідженні приводиться діагностика та рекомендації щодо розвитку складових компонентів дитячого лікувального комплексу на рівні містобудівної мережі закладів ТМД у межах м. Києва. Як свідчить аналіз територіального розміщення існуючих в Києві дитячих лікарень, їх основна частина знаходиться на правобережній частині міста (16 лікарень) і лише 1 - на лівому березі міста. 317 дитячих лікарень 3 складають спеціалізовані дитячі лікувальні заклади (інфекційний, туберкульозний та нейрохірургічний профілі), 10 - комунальні та 4 приватні лікарні дитячого призначення. Враховуючі вищенадані пропозиції стосовно інтеграції дитячих відділень у склад 22 лікарень містобудівної мережі закладів ВМД Києва, пропонується такий розподіл: організація 1 університетської лікарні, до складу якої входять суміжні за місцем розташування Київська міська дитяча клінічна лікарня № 2, Київська міська клінічна лікарня № 3 та пологовий будинок № 6; 4 дитячі спеціалізовані лікарні республіканського значення за профілем лікування: Київська міська дитяча клінічна інфекційна лікарня (інфекційний профіль), НДСЛ «Охматдит» (онкологічний профіль), Київська міська дитяча клінічна лікарня № 1 (нефрологічний та кардіологічний профіль), Дитяча клінічна лікарня № 7 (нейрохірургічний профіль); 4 дитячі лікарні: Дитяча клінічна лікарня № 4, Дитяча клінічна лікарня № 6, Дитяча клінічна лікарня № 8, Дитяча клінічна лікарня № 9.

Метод генеративності покликаний на активізацію динамічного та закономірного синергетичного просторово-часового розвитку містобудівної системи закладів охорони здоров'я, іiі структурних ієрархічних територіальних мереж й лікувальних комплексів шляхом поступової самоорганізації та саморегуляції складових компонентів. На державному містобудівному рівні метод впроваджується через прийом поєднаності, дія якого виявляється у 
територіальній проекції та корегуванні шляхів реалізації загального змістовного вектору розвитку містобудівної системи лікувальних закладів залежно від сукупності особливостей регіонів країни. Прийом відмінності пов'язаний 3 динамічним оновленням компонентів містобудівних мереж ПМД, ВМД та ТМД у містобудівному середовищі найкрупніших, крупних та великих міст залежно від низки змінних внутрішніх та зовнішніх факторів розвитку та функціонування. Прийом подібності, призначений для територій середніх та малих міст, сільської місцевості дозволяе в разі потреби зменшувати місткість та потужність лікувальних закладів 3 метою доступного забезпечення мешканців малонаселених пунктів медичною допомогою.

Метод скупчення покликаний на сумарну інтегративність складових компонентів медичних кластерів, забезпечуючи типологічне різноманіття цілісності лікувальних угрупувань. Прийом взаємозв'язковості, сила дії якого розкривається на державному планувальному рівні організації містобудівної системи закладів охорони здоров'я, відповідає за встановлення комунікаційних зв'язків між окремими групами медичних кластерів. Прийом інтегращіï у середовищі найкрупніших, крупних та великих міст активізує виконання функції декількох рівнів медичного обслуговування в межах одного лікувального комплексу або закладу. Прийом розсіювання у середовищі середніх та малих міст, сільської місцевості скеровує вектор формування медичних кластерів у напряму розрідженого розгалуження містобудівного розміщення лікувальних закладів, 3 метою попередження їх концентрації на певній території i, як наслідок, зменшення радіусу медичного обслуговування населення.

Метод контекстуальності передбачає індивідуальний шлях формування і розвитку містобудівної системи лікувальних закладів України з урахуванням кращого світового досвіду та тенденцій територіального розміщення сукупності будівель медичного призначення. На загальнодержавному рівні пропонується використання прийому протиставлення, зміст якого полягає у осмисленому зіставленні фактичного стану містобудівної системи закладів охорони здоров'я, іiі складових мереж та лікувальних комплексів з прогнозним станом, пошуком відхилень та рішень щодо корегування. Прийом палімпсесту у міському середовищі найкрупніших, крупних та великих міст призначений для урахування історично значущих лікувальних будівель та установ, їх 
інтеграції, збереженні та оновленні у межах перспективного розвитку містобудівної системи. Прийом новаційності у містобудівному середовищі середніх та малих міських поселень, територій сільських населених пунктів дозволяє впроваджувати нові форми організації медичного обслуговування населення.

\section{ВИСНОВКИ}

1. Дослідження містобудівної системи охорони здоров'я, питань об'єднання та взаємної узгодженості складових елементів цілісності проведено на підгрунті системного підходу, який дозволив розглянути мережу дитячих лікувальних закладів як ієрархічно підпорядковану цілісність лікувальних комплексів, інтегрованих у госпітальні кластери та округи, в яких об'єднуються і взаємодіють елементи системи - містобудівні мережі закладів різних рівнів медичної допомоги.

2. Розглянуто та науково обгрунтовано новий містобудівний об'єкт - дитячий лікувальний комплекс, який набуває цілісного характеру завдяки упорядкованій послідовності мереж лікувальних закладів первинного (ПМД), вторинного (ВМД), третинного (ТМД) рівнів медичної допомоги. Лікування дітей на первинному рівні медичного обслуговування відбувається у закладах ПМД у межах сімейної медицини, на вторинному рівні - в інтегрованих дитячих відділеннях лікарень ВМД, на третинному рівні - у спеціалізованих дитячих та інших лікарнях ТМД.

3. Концепція перспективного розвитку містобудівної системи закладів охорони здоров'я базується на системному підході, враховує нові засадничі медичні положення та принципи, притаманні сучасній архітектурно-містобудівній практиці. Запропоновано матрицю принципів для різних типів міського середовища, яка складається з 6 базових та 18 похідних принципів: розосередження (розгалуженість, локальність, детермінованість), комплексність (синтезування, повторення, розсіяння), іррегулярність (поляризація, концентрація, розрідженість), фрактальність (тяжіння, метаболізм, повторювання), кластерність (інтегральність, консолідованість, комутаційність), своєрідність (регіональність, ідентичність, ініціалізація). Сформульовані 6 груп методів і 18 практичних прийомів реалізації. 


\section{АНОТАЦІЯ}

Розглянуто актуальність дослідження питань містобудівного розвитку системи закладів охорони здоров'я в умовах реформування медичної сфери. Незважаючи на те, що держава витрачає значну частину ВВП на охорону здоров'я, якість і рівень медичного забезпечення в Україні залишається незадовільним. Це явище викликано тим, що українська система охорони здоров'я $\epsilon$ громіздкою та застарілою, в тому числі в архітектурномістобудівному аспекті, базуючись на радянській організаційній моделі. Складну ситуацію провокують глибинні недоліки, накопичені 3 80-х pp. XX ст. у національній системі охорони здоров’я через відсутність поетапної модернізації. 3 цієї позиції у дослідженні запропоновані принципи, методи та прийоми територіальної організації містобудівної системи закладів охорони здоров’я. Матриця принципів для різних типів міського середовища складається з 6 базових та 18 похідних принципів: розосередження (розгалуженість, локальність, детермінованість), комплексність (синтезування, повторення, розсіяння), іррегулярність (поляризація, концентрація, розрідженість), фрактальність (тяжіння, метаболізм, повторювання), кластерність (інтегральність, консолідованість, комутаційність), своєрідність (регіональність, ідентичність, ініціалізація).

\section{ЛIТЕРАТУРА}

1. Булах I.B. Передумови реорганізації мережі дитячих лікувальних закладів України. Сучасні проблеми архітектури та містобудування. Київ, 2017. № 47. С. 444-450. URL: http://library.knuba.edu.ua/books/zbirniki/01/201747.pdf.

2. The Legatum Institute: рейтинг розвитку медицини в країнах світу в 2017 p. URL: https://www.li.com/.

3. Булах I.B. Сучасний закордонний досвід проектування енергоефективних лікарень (досвід Сінгапура). Сучасні проблеми архітектури та містобудування. Київ, 2018. № 50. С. 332-440. URL: http://library.knuba.edu.ua/books/zbirniki/01/2018/201850.pdf.

4. Булах І.В. Досвід організації системи охорони здоров'я у Сполучених Штатах Америки та Франції із визначенням в них місця мережі дитячих лікувальних закладів. Сучасні проблеми архітектури та містобудування. Київ, 2018. № 52. С. 165-173. URL: http://library.knuba.edu.ua/books/zbirniki/01/2018/201852.pdf. 
5. Булах І.В. Архітектурно-містобудівна організація закладів охорони здоров'я Німеччини та Великобританії. Сучасні проблеми архітектури та містобудування. Київ, 2019. № 53. С. 126-134. URL: http://library.knuba.edu.ua/books/zbirniki/01/2019/201953.pdf.

6. Міністерство охорони здоров'я: Національна стратегія реформування системи охорони здоров'я в Україні на період 20152020 років. URL: http://moz.gov.ua/uploads/0/691-strategiya.pdf.

7. Bulakh I., Kozakova O., Didichenko M. The innovative trends in architecture and urban planning of health care institutions. International Journal of Innovative Technology and Exploring Engineering. Bhopal, 2019. Vol.9. Issue 1. Pp. 317-323. DOI: 10.35940/ijitee.A4111.119119.

8. Bulakh I., Kozakova L., Didichenko M., Chala O. Health Care Architectural and Urban Planning Systems In The United States of America and France. International Journal of Innovative Technology and Exploring Engineering. Bhopal, 2019. Vol. 9(2). Pp. 1622-1627. DOI:10.35940/ijitee.B7377.129219.

9. Bulakh I.V. Artistic and Aesthetic Formation and Evolution of Architectural and Urban Planning Space. Science and Innovation. Kyiv, 2019. Volume 15. No 5(5). Pp. 57-66. DOI: 10.15407/scine15.05.057. URL: http://scinn-eng.org.ua/archive/15\%285\%29/15\%285\%2904.

\section{Information about author: Bulakh I. V.,}

Candidate of Architecture, Associate Professor, Associate Professor of Department of Design Architectural Environment Kyiv National University of Construction and Architecture 31, Povitroflotskyy Ave., Kyiv, 03037, Ukraine 